\title{
WOMEN AND CHILDREN EMPOWERMENT THROUGH LEARNING ENGLISH: COLLABORATING WITH JAGE KESTARE FOUNDATION
}

\author{
Puspita Dewi1 ${ }^{*}$, Riyana Rizki Yuliatin², Isra Dewi Kuntary Ibrahim ${ }^{3}$, Nurul

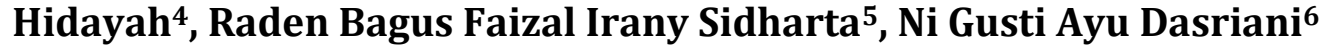 \\ 1,3,4,5,6 Universitas Bumigora, Mataram, Indonesia \\ ${ }^{2}$ Universitas Hamzanwadi, Selong, Indonesia \\ * Penulis Koresponsensi, email: puspitadewi@universitasbumigora.ac.id
}

\begin{abstract}
English as a lingua Franca has a special attention for people or children to learn the skill including for children and young people in Ungga village. It is because the language is one of the tools to communicate with other people such as for education, business, tourism, politics, and other sectors. Ungga has a good potency to be developed in promoting the village to be one of tourism places in central Lombok because it near to the Mandalika spots. Consequently, the human resources are needed to be prepared related to the knowledge and the skills. One of the ways to achieve the goals is providing English training either for the young people or for the children. Teaching English has numerous challenging. However, by designing collaborative learning with some games would encourage them in learning. Children enjoy playing games both online or offline with the peers or friends so that collaborative learning by designing a fun concept is one of the effective ways to teach and learn English. Several games were provided such as guess voices, mix and match and Find Friends. Besides, partnership among universities, village officers and communities are crucial to maintain the sustainability so that the university collaborated with one of the communities in the village "Jage Kestare Foudation" to conduct the activity. Teaching English learning goal is not only for learning English but also incorporating gender equality values in teaching and learning process through materials and activities. The results of the community service activity are that the learners become more active in learning English and more aware of gender equality values. It is expected that by empowering the women and children in the village through learning English by incorporating gender values, it will be able to empower the communities particularly for women and children and to gain revenue generating.
\end{abstract}

Keywords: Women empowernment; English; Collaboration

Abstrak. Bahasa Inggris sebagai lingua Franca memiliki perhatian khusus bagi masyarakat untuk mempelajari keterampilan tersebut termasuk untuk anak-anak dan remaja di desa Ungga. Bahasa merupakan salah satu alat untuk berkomunikasi yang digunakan orang lain dalam dunia pendidikan, bisnis, pariwisata, politik, dan sektor lainnya. Ungga memiliki potensi yang baik untuk dikembangkan dalam mempromosikan desa tersebut menjadi salah satu tempat wisata di Lombok Tengah karena dekat dengan tempat-tempat pariwisata, salah satunya adalah Mandalika dan Moto GP. Oleh karena itu, perlu disiapkan sumber daya manusia yang terkait dengan pengetahuan dan keterampilan yang mumpuni. Salah satu cara untuk mencapai tujuan tersebut adalah dengan memberikan pelatihan bahasa Inggris baik untuk kaum muda maupun untuk anak-anak. Mengajar bahasa Inggris memiliki banyak tantangan. Namun, dengan merancang pembelajaran kolaboratif dengan beberapa permainan akan mendorong mereka dalam belajar. Anak-anak senang bermain game baik online maupun offline dengan teman sebayanya sehingga pembelajaran kolaboratif dengan merancang konsep yang menyenangkan merupakan salah satu cara efektif untuk mengajar dan belajar bahasa Inggris. Beberapa permainan yang disediakan seperti tebak suara, mix and match, dan Find Friends. Selain itu, kemitraan antara perguruan tinggi, perangkat desa dan masyarakat sangat penting untuk menjaga keberlanjutan sehingga universitas bekerjasama dengan salah satu komunitas di desa Ungga yaitu "Yayasan Jage Kestare" untuk melakukan kegiatan tersebut. Tujuan pembelajaran pengajaran bahasa Inggris tidak hanya untuk belajar bahasa Inggris tetapi juga memasukkan nilai-nilai kesetaraan gender dalam proses belajar mengajar melalui materi dan kegiatan. Hasil dari kegiatan pengabdian masyarakat ini peserta didik dapat menjadi lebih aktif dalam belajar bahasa Inggris dan lebih sadar akan nilai-nilai keadilan gender. Diharapkan dengan memberdayakan perempuan dan anak-anak di desa melalui pembelajaran bahasa Inggris dengan memasukkan nilai-nilai gender, akan mampu memberdayakan masyarakat khususnya bagi perempuan dan anak-anak untuk lebih menyadari akan nilai-nilai keadilan gender dan dapat menghasilkan pendapatan lebih.

Kata Kunci: Pemberdayaan perempuan, Bahasa Inggris, Kolaborasi

How to Cite: Dewi, P., Yuliatin, R.R., Ibrahim, I.D.K., Hidayah, N., Sidharta, R. B. F. I., \& Dasriani, N.G.A.(2021). Women and Children Empowerment through Learning English: Collaborating with Jage Kestare Foundation. Mitra Mahajana: Jurnal Pengabdian Masyarakat, 2(3), 267-273. doi: https://doi.org/10.37478/mahajana.v2i3.1228 


\section{INTRODUCTION}

Universities become a hope for society to tackle and assist the society to solve numerous problems because collages are a place that can create generation who can lead the country to be better quality through education. Strengthening link and collaboration among all stakeholders would be a big power to change the better world because conducting partnership and collaboration will affect on more significant alterations including in promoting equality, reducing violence, and improving better quality for communities. Consequently, building partnership among the institutions, communities, organizations, and universities have good power to form better societies.

Empowering human resources through education is one of the keys to empower villages because the better quality of the human resources, the better the villages will be. Therefore, villages need to be facilitated to gain more information, positive feedbacks, suggestions, and trainings. For instance, socializing of technology, teaching English or other foreign languages, socializing the reproductive health and other community service activities are good illustration to contribute to the villages. Teaching English by imbedding technology and gender values is believed that it will be wider the learners comprehension and knowledge.

Several ways could be taken to empower the society such as encouraging them to learn foreign Language (English), technology, reproductive health and other sectors. In this community service activity, Universitas Bumigora team conducted empowerment through teaching English. English is one of the most fundamental aspect that the society particularly women and children to master the language because Lombok becomes one of the most interesting destinations in Indonesia visited by international travellers. As the result, learning English could support them to reach the local government's target in which numerous villages can be tourism sport and could gain incomes.

Tourism spot has been encouraged since several years ago and nowadays local government created programs to support villages to be tourism spots, moreover Moto GP projects that will be one of the most interesting programs in Mandalika, Central Lombok. Consequently, a team from Universitas Bumigora conducts the community service to teach English for women and children in Ungga collaborated with one of the communities in the village namely Jaga Kestare Foundation. This activity embraces a local community "Jake Kestare Foundation" that concerns on society empowerment and education.

Learning English is expected to support the children and young people in Ungga village in enhancing their English speaking skill so that they can promote and able to be tour guides. Furthermore, they can obtain additional income and support their finances. The community service activity is designed not only to transfer the knowledge and assist for the income but also to instil the gender equality values during learning process such as leadership, responsibility, respect, equality, and confidence. Through the training, the learners are expected to utilize the knowledge gained for obtaining revenue generating. Reddy (2016) notes that:

\footnotetext{
"English is essential for getting a good job and better salaries. Multinational business organizations and many international corporations ask for people who have a good working knowledge of English. Even job adverstisements in local market also require English knowing people. People who go abroad for work also need to know English. English is needed for a variety of jobs as like air hostess, pilot, travel guide, media manager, and the others"
}

Teaching and learning English for children and young people have challenging because English is not their second language but foreign language. The learners acquire the language by learning it conciousley. As a result, plenty of methods could be applied including collaborative learning. It is one of the most effective methods used to encourage the students' activation and increase their motivation to learn. The collaborative Learning aim is not only for collaboration activities but also for sharpening the learners' cognitive because CL could develop both skills (Le et al., 2018). It is relevant to Häkkinen et al. (2020) notion that the CL contributes to the academic skill and "soft" personal characteristics, such as beliefs, motivation, perception, 
behaviours, and attitudes. Interaction between students and teachers has good effect on students' achievements in which Tang et al. (2018) mention that students' and teachers' engagement with theory practice connect to cognitive complexity and personal characters development.

\section{METHODS}

The modified ABCD method was used to assist the communities to be more aware on the village and human resource potencies. In addition, the collaborative learning method was applied in this community service activity to encourage the learners to be more excited to learn by providing games. The ABCD method was modified by focusing on one item in which Tamam \& Fahimah (2020) note that one of the ABCD method aims is to encourage individuals and communities' development through encouraging the inhabitants by conducting changes for better life. One of the methods used is analysing the potency of the village and encouraging or empowering the society to utilize the potency to be more advantageous socially or economically. Based on the observation and interview, there are some needs of Ungga village shown in Table 1:

Table 1. The Needs Analysis

\begin{tabular}{ll}
\hline Needs Analysis Items & \multicolumn{1}{c}{ Priority Scale } \\
Silversmith & Promoting the silversmith nationally and internationally \\
Traditional food & Promoting products \\
Digital Village & Websites \\
\hline
\end{tabular}

Based on the need analysis, Ungga has a good potency of silversmith and traditional food that can be promoted to national and international tourists because Ungga is near to the airport in which many tourists probably will visit the village. To broaden the links and the trade of the business, the inhabitants need to master English as one of the international languages. Consequently, English skill is needed to children and women in the village so that they can improve their income and assist the family finance.

\section{FINDINGS AND DISCUSSION}

The community service was conducted in Ungga village, Central Lombok. Based on the needs analysis, the village has several potencies such as the natural resources involving silversmith and the human resources. The opportunity might be good chance for the community to develop their income and economic sectors. Universitas Bumigora collaborated with Jaga Kestara Foundation held the community service by teaching English for women and children in the village to develop their skills so that they could be empowered and encouraged. The activity is concerned on Learning English, especially speaking skill. This program is expected to be able to elicit the children and women to learn English and encourage them to utilize the village potencies so that they can improve their skills and environment.

Collaborative learning was conducted in which the tutor explain and pronounced the vocabularies available and the learners were constructed to follow the tutor. Drilling strategy was implemented to drill the students to speak. Afterwards, the students were divided into some groups and every group has a leader. The leader leads, encourages, and motivates the members. The leaders are not only from men but also women to pursue equality and to empower women. Collaborative Learning Approach (CLA) was used in this community service activity in which the teaching and learning process was designed by groups and collaborations because this method encourage the learners to collaborate each other to achieve educational goals (Loes et al., 2018).

The learners were taught several topics namely numbers, colours, animals, days, and nouns around you. The collaborative learning was applied in which the students were in groups and every group must mix and match between the animal pictures and their definitions. The collaborative learning was implemented by making competition of guess what colours and days. While they learn of days, they also learn of colours. In the previous explanation, the tutors 
explain that Sunday correlate with brown and other days with other colours. Therefore the materials are competed amidst groups by answering quickly the numbers or days mentioned by tutors. The group who answers the questions faster is to be a winner. The indoor class was continued in outdoor class in which the activity is searching the colours around them and touched it based on the days mentioned. Every group discovered quickly and run together to touch the stuffs with their group members.

In the third week, the tutor provides some vocabularies related to nouns around them such as traffic light, bananas, couple, trees, and gazebo. Playing a game is one of the most interactive methods in learning languages. Playing find friends is the game used to learn the vocabularies. All students make a big circle; afterwards, the tutor explains the game. There 10 vocabularies in which the tutor explains each word and the definition. For instance, when a word couple pronounced by the tutor; it means "couple" the pupil need to search a friend, traffic light means "three people must together", gazebo means a learner need to join with 5 people. In short, the learners can learn fun and learn about collaboration with teams.

In the fourth week, the team and Jage Kestare Foundation provided a short movie about children who have different ability to be watched and elicited the learners to identify the meaning of the movie. It is expected that by watching the movie, the children aware of differences among their friends and prevent for bullying. Beside, the learners gain several new inputs (vocabularies) from the movie. After watching the movie, the children were instructed to reflect the movie and correlated with their daily life. In addition, the learners were instructed to comment the movie.

The tool was designed to attract the students' enthusiasms and motivation. The tool was designed by one of IT lecturers in Universitas Bumigora based on the Internet of Things (IoT) in which the learners were encouraged to pronounced some words and the lamp will off and on. If the learners pronounced the word correctly, the lamp was on or it is off. However, if the pronunciations were wrong; the lamp did not work. The students are motivated to practice their English because of the tool. Many students were excited to try the tool and check their pronunciation. Learning through ICTs develop students' critical thinking so that schools are strongly encouraged to combine the cutting-edge technology in their teaching and learning process and for all learning levels (Fu, 2013).

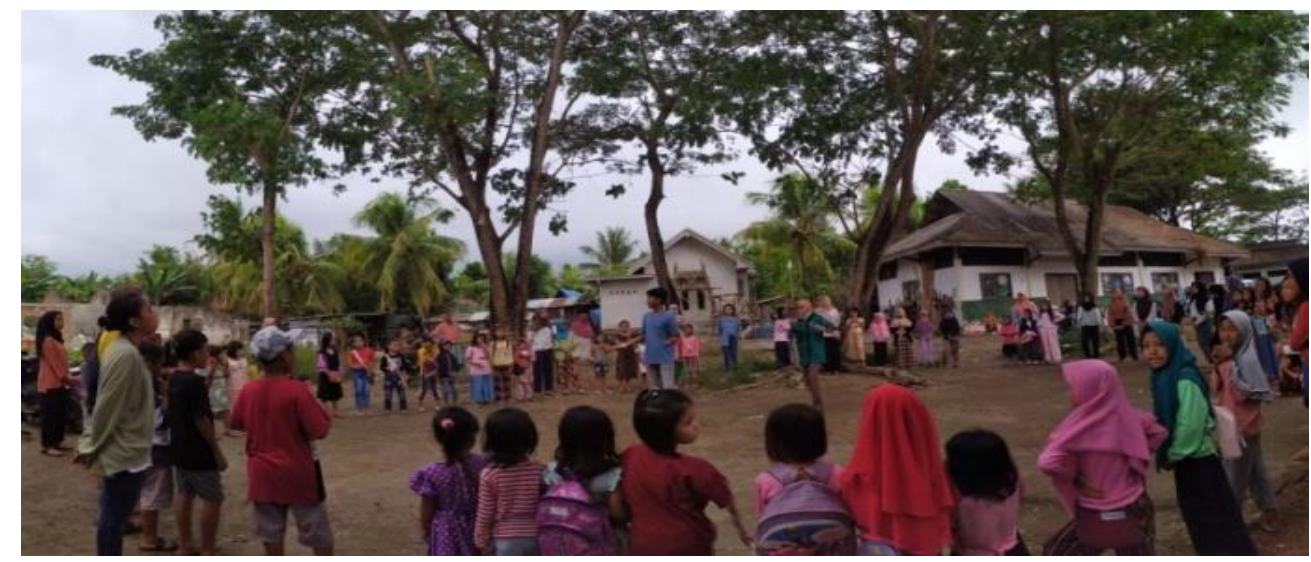

Picture 1. Learning Outside (Fun Game)

Learning English through Information and Technologies (ICTs) by designing a tool based on the Internet of Things (IoT) in the teaching and learning process is remarkably effective for the learners because either children or young people have hand phone and use frequently the internet in daily life. Collaboration among teachers, pupils, and technology are probably to be able to support the learners to feel excitement in in learning so that the objectives of the study can be achieved easily. In this community service, the activity is 
incorporated technology and IoT in teaching and learning English. Mukhtarov et al., (2019, p.289) note:

\begin{abstract}
"These may be 'cognitive' covering changes in beliefs and attitudes, and 'behavioural' covering changes in the way actors behave, and in more structural changes in implementing new policy innovations on the ground. There is a special emphasis in the framework on contextual factors that enable or constrain collaborative learning, such as structural, social, and technological features of collaboration".
\end{abstract}

The learners have different of learning style and preference. Dewi \& Muhid (2021) state that learning style are influenced by technology and modernization; it depends on the generation. Gen-Z and millennial prefer to use hand phone plenty of hours to read books so that it is needed to modified the methods, approaches, or strategies in teaching.
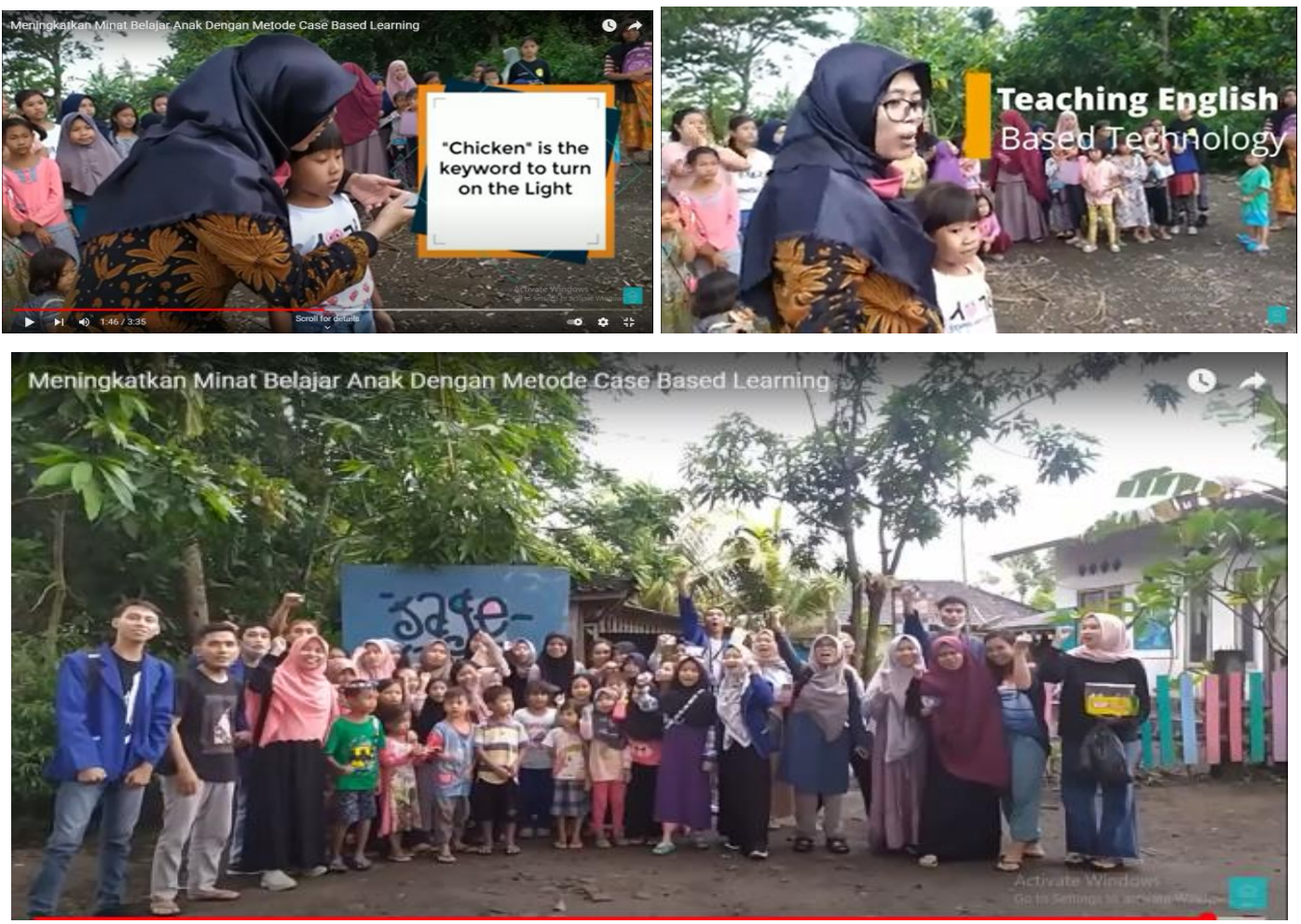

Picture 2: Pictures the results of the activity documentation

Collaborative learning is one of the most effective methods used in learning English or other foreign language because the pupils can ask their friends and motivate their friends when one task is difficult to be accomplished. Arta (2019) states that collaborative learning plays significant role in enhancing and develop learners' speaking skill because collaborative learning reduce learners' anxiety, increase confidence, and motivate the students' participation and collaborative learning helps the learners to acquire learning experiences (Tristanti \& Suharta, 2018) such team work, responsibility, and respect. The games applied in the community service are designed based on collaborative learning because CL is believed that can motivate students to engage in classroom activity and to elicit learners' interactions. it is also supported by ai $(2011,2013)$ mentions that collaborative learning is believed that has a good potential in boosting students learning (Ajayi \& Ajayi, 2020). The gist of the collaborative learning is to prevent an instructor-centered classroom so that tutors focus on providing and materials and facilitating the students in learning (Loes et al., 2018). Drilling and imitating through collaborative learning probably could help learners to undertand easily about materials learnt. Chaikin (2003) citen in (Newman et al., 2020, p.10):

"The crucial assumption is that imitation is possible because (a) maturing psychological functions are still insufficient to support independent performance but (b) have developed sufficiently so that (c) a person can understand how to use the collaborative actions (e.g., leading questions, demonstrations) of another. (Chaiklin 2003, 52)"

271 | WOMEN AND CHILDREN EMPOWERMENT THROUGH LEARNING ENGLISH: COLLABORATING ... KESTARE FOUNDATION 
It is expected that by learning English becomes one of other viable solutions to encourage women and children to obtain incomes and through learning English would be able to change the learners' perspectives to be better by selecting dictions and sentences used during the learning. The instruction and materials plays crucial role because languages and words selection used in shaping students' perception and their behaviours and attitudes (Dewi et al., 2021). Learning language is more flexible to incorporate numerous values. Languages or texts can be deconstructed and constructed in which the children or learners learn about cultural identities (Botelho \& Marion, 2020). Gender equality values were imbedded in the teaching and learning process to enhance the learners' awareness and to promote gender equality. Both men and women were given the same opportunity to learn, to speak, and to exposure themselves.

Gender inequality becomes one of the most challenging throughout the world in which women live in patriarchy and frequently gain abuse, violence, and other unfair treatments. Imbedding gender values is one of the main goals of this activity because it is crucial for women and children to be more aware of gender equality issues. Women and children frequently to obtain violence, bullying, and other intimidations so that empowering them through education is expected to reduce the matters and strengthen them to reach better future. Many communities and universities do collaboration to conduct the community service to empower the society particularly for women and children because gender inequalities become one of the most challenging throughout the world.

The community service learning plays a pivotal role in developing social skills through empowering the qualities of the human resources and instils good values such as responsibility, honesty, respect, and other values (Afzal \& Hussain, 2020). Because, it is believed that he quality of human interaction and communication can be enhanced through inculcating social skill from childhood by imbedding social values and helping each other (Afzal \& Hussain, 2020). Afterwards, through collaborative learning pursues learners to learn actively and establish connection among the learners (Maharani et al., 2020).

\section{CONCLUSION AND FOLLOW UP}

Collaborative learning has good impact on learning English in Ungga village by designing fun concept that providing several games. This community service encourages gender equality concept by providing the same opportunity to both men and women to gain education. In the activity also women are led to be leader to reach one of the SDGs targets. Enhancing links and collaboration with other partners is expected to gain the goals faster and more sustainable. Therefore, Universitas Bumigora invited Jaga Kestare Community to strengthen the programs and assist teams in implementing the community service. Consequently, among stakeholders should hold together to take responsibility to empower children, youth, women, and all citizens for better Indonesia future.

\section{REFERENCES}

Afzal, A., \& Hussain, N. (2020). The Impact of Community Service Learning on the Social Skills of Students. Journal of Education and Educational Development, 7(1), 55. https://doi.org/10.22555/joeed.v7i1.2988

Ajayi, P. O., \& Ajayi, L. F. (2020). Use of online collaborative learning strategy in enhancing postgraduates ' learning outcomes in science education. Educational Research and Reviews, 15(8), 504-510. https://doi.org/10.5897/ERR2020.4023

Arta, B. (2019). Multiple Studies: The Influence of Collaborative Learning Approach on Indonesian Secondary High School Students' English-Speaking Skills. English Language Teaching Educational Journal, 1(3), 149. https://doi.org/10.12928/eltej.v1i3.143

Botelho, M. J., \& Marion, R. (2020). Representing Spanishes: Language Diversity in Children's Literature. Journal of Latinos and Education, 00(00), 1-16. https://doi.org/10.1080/15348431.2020.1763353 
Dewi, P., \& Muhid, A. (2021). Students ' Attitudes t owards Collaborative Learning through ELearning during Covid-19: A Male and Female Students. English Teaching Journal: A Journal of English Literature, Linguistics, and Education, 9(1), 26-33. https://doi.org/10.25273/etj.v9i1.9046

Dewi, P., Yuliatin, R. R., Magfirah, S., Sari, Di. E., \& Maricar, F. (2021). Promoting Gender Equality Values in a Fiction Written by A Lombok Female Writer. International Journal of Linguistics, Literature and Translation, 4(3), 17-21. https://doi.org/10.32996/ijllt

Fu, J. S. (2013). ICT in Education : A Critical Literature Review and Its Implications. International Journal of Educational and Development Using Information and Communication Technology (IJEDICT), 9(1), 112-125.

Häkkinen, P., Virtanen, T., Virtanen, A., Näykki, P., Pöysä-Tarhonen, J., Niilo-Rämä, M., \& Järvelä, S. (2020). Finnish pre-service teachers' perceptions of their strategic learning skills and collaboration dispositions. Journal of Education for Teaching, 46(1), 71-86. https://doi.org/10.1080/02607476.2019.1708628

Le, H., Janssen, J., \& Wubbels, T. (2018). Collaborative learning practices : teacher and student perceived obstacles to effective student collaboration. Cambridge Journal of Education, 48(1), 103-122. https://doi.org/10.1080/0305764X.2016.1259389

Loes, C. N., Culver, K. C., \& Trolian, T. L. (2018). How Collaborative Learning Enhances Students' Openness to Diversity. Journal of Higher Education, 89(6), 935-960. https://doi.org/10.1080/00221546.2018.1442638

Maharani, R., Marsigit, M., \& Wijaya, A. (2020). Collaborative learning with scientific approach and multiple intelligence: Its impact toward math learning achievement. Journal of Educational Research, 113(4), 303-316. https://doi.org/10.1080/00220671.2020.1806196

Mukhtarov, F., Dieperink, C., Driessen, P., \& Riley, J. (2019). Collaborative learning for policy innovations: sustainable urban drainage systems in Leicester, England. Journal of Environmental Policy and Planning, 21(3), 288-301. https://doi.org/10.1080/1523908X.2019.1627864

Newman, S., Latifi, A., \& Newman, S. (2020). Vygotsky, education , and teacher education Vygotsky, education , and teacher education. Journal of Education for Teaching, 00(00), 114. https://doi.org/10.1080/02607476.2020.1831375

Reddy, M. S. (2016). Importance of English Language in today's World. International Journal of Academic Research, 3(4), 2348-7666. www.ijar.org.in

Tamam, A. B., \& Fahimah, S. (2020). Pengembangan Agrowisata Berbasis Komunitas Melalui Program Edukasi Wisata dan Entrepreneurship Menuju Kemandirian Ekonomi Masyarakat. Engagement: Jurnal Pengabdian Kepada Masyarakat, 4(1), 100-115. https://doi.org/10.29062/engagement.v4i1.139

Tang, S. Y. F., Wong, A. K. Y., Li, D. D. Y., Cheng, M. M. H., Tang, S. Y. F., Wong, A. K. Y., Li, D. D. Y., \& Cheng, M. M. H. (2018). Examining student teachers ' engagement with the theory-practice link in initial teacher education practice link in initial teacher education. Journal of Education for Teaching, 00(00), 1-17. https://doi.org/10.1080/02607476.2018.1548167

Tristanti, T., \& Suharta, R. B. (2018). Model of Collaborative Learning to Improve Student's Learning Ability in Nonformal Education Departement. Journal of Nonformal Education, 4(2), 177-186. https://doi.org/10.15294/jne.v4i2.16007 